\title{
Study of Genetic Polymorphisms of Vascular Endothelial Growth Factor in Women with Recurrent Abortion
}

\author{
Rizk El-baz ${ }^{1}$, Mohamed H. Bedairy ${ }^{2}$, Ahmed M. Saad ${ }^{3}$, Mohamed S. El-gareeb ${ }^{4}$ \\ 1(Department of Biochemistry, Faculty of Medicine/ Mansoura University, Mansoura, Egypt) \\ 2(Department of Obstetrics \& Gynecology, Faculty of Medicinel Mansoura University, Mansoura, Egypt) \\ 3(B.Sc. Chemistry, Faculty of Sciencel Mansoura University, Mansoura, Egypt) \\ 4(Department of Chemistry, Faculty of Sciencel Port Said University, Port Said, Egypt)
}

\begin{abstract}
Vascular endothelial growth factor (VEGF) regulates endothelial cell proliferation, migration and differentiation. VEGF plays a critical role in angiogenesis during placenta formation. We investigated whether VEGF gene polymorphisms are associated with recurrent pregnancy loss. One hundred women with recurrent abortion and 100 control women with live-born children were recruited from healthy Egyptian women. VEGF gene polymorphisms were assessed with PCR-RFLP analysis of DNA samples obtained from peripheral blood. DNA fragments were investigated by using appropriate primers. SNP scanning was performed using MnII, BgIII, BsfmI, and NIaII restriction enzymes for $1154 \mathrm{G} / \mathrm{A}, 2578 \mathrm{C} / \mathrm{A}, 634 \mathrm{C} / \mathrm{G}$, and $936 \mathrm{C} / \mathrm{T}$ polymorphisms, respectively. Recurrent abortion among Egyptian women was strongly associated with the mutations related to VEGF gene polymorphism. Interestingly, VEGF $1154 \mathrm{G} / \mathrm{A}, 2578 \mathrm{C} / \mathrm{A}$ and $634 \mathrm{C} / \mathrm{G}$ mutation frequencies were significantly higher different between the controls and women with recurrent abortion. However, the $936 \mathrm{C} / \mathrm{T}$ was not significantly in women with recurrent abortion.
\end{abstract}

Key words: Polymorphisms; Recurrent abortion; VEGF.

\section{Introduction}

The term 'Abortion' is applied to many complications of early pregnancy, and it is important to be clear on terminology. In 2005, the European Society of Human Reproduction and Embryology (ESHRE) introduced a revised terminology regarding early pregnancy events (1). A pregnancy loss that occurs after a positive urinary human chorionic gonadotropin (hCG) or a raised serum $\beta$-hCG but before ultrasound or histological verification is defined as a 'biochemical loss'. In general, these occur before 6 weeks of gestation. The term clinical miscarriage is used when ultrasound examination or histological evidence has confirmed that an intrauterine pregnancy has existed. Clinical miscarriages may be subdivided into early clinical pregnancy losses (before gestational week 12) and late clinical pregnancy losses (gestational weeks 12 to 21). There is no consensus on the number of pregnancy losses needed to fulfill the criteria for recurrent Abortion (RA), but ESHRE guidelines define RA as three or more consecutive pregnancy losses before 22 weeks of gestation (2). Although the above-mentioned terminology is widely used, it is also acknowledged that it is not always clinically useful. Indeed, a recent paper has proposed classification according to developmental periods in gestation (3).

One percent to $5 \%$ of pregnant women with recurrent abortions (RA) of which $40 \%-55 \%$ are induced by unknown causes (4-6). Known etiologic factors of RA are parental chromosome abnormalities, uterine abnormalities, hereditary thrombophilia, endocrinologic disorders, immunologic factors, infections, and nutritional and environmental factors (7).

Vascular endothelial growth factor (VEGF) induces endothelial cell proliferation and migration, enhances vascular permeability, reduces endothelial cell apoptosis and promotes stromal proteolysis (8). The VEGF family includes placenta growth factor, VEGF-A, VEGF-B, VEGF-C, VEGF-D, and VEGF-E. VEGF A is the most potent angiogenic factors.

VEGF plays an important role in fetal and placental angiogenic development. VEGF also plays a major role in oocyte maturation, embryo implantation/ development, decidualized endometrial vascularization and placenta angiogenesis/ vascularization in early gestation (9). In early pregnancy, the status of chorionic villi vascularization is related to embryonic development, and reduced placental trophoblastic VEGF level has been described in the decidual endothelium of spontaneous miscarriages (10). Several VEGF polymorphisms have been reported to affect VEGF activity and expression $(11,12)$.

Various studies have investigated the association of VEGF gene polymorphisms with diseases in which angiogenesis plays a major role in pathogenesis, such as diabetic retinopathy (11), renal cell carcinoma (13), acute renal allograft rejection(14), malignant melanoma (15) and other malignancies $(16,17)$. The results, however, were mixed. It is reported that VEGF A -2578 AA genotype is a risk factor and -2578 CC genotype is a protective factor for myocardial infarction (18). A relationship between VEGF gene and breast cancer was 
reported in different studies. Accordingly, the TT genotype for $+936 \mathrm{C} / \mathrm{T}$ polymorphism reduces breast cancer risk (16). In different studies, a relationship between VEGF -1154G/A, -2578C/A, + 936C/T polymorphisms and recurrent pregnancy loss were reported $(8,19)$.

Abortion etiology is still mostly unknown, but genetic factors are the most effective group. We hypothesized that VEGF polymorphisms in fetal genotype could be risk factors for spontaneous abortion and analyzed $-1154 \mathrm{G} / \mathrm{A},-2578 \mathrm{C} / \mathrm{A},-634 \mathrm{C} / \mathrm{G}$ and $-936 \mathrm{C} / \mathrm{T}$ polymorphisms in Egyptian Women.

\section{Material and method}

The study participants included 100 female cases with a history of 2 or more events of recurrent abortion (spontaneous abortion, miscarriage or still birth). Their mean age \pm SD was $28.5 \pm 5.91$ years. Seventy three (73\%) cases had a history of recurrent early abortions, $8(8 \%)$ had a history of late abortions and the other $19(19 \%)$ cases had a history of both early and late abortions. Two (2\%) were diabetic, $24(24 \%)$ had a history of passive smoking, three (3\%) were hypertensive and 22 cases (22\%) had a positive ELISA test for TORCH infection (Toxoplasma Gondii, Rubella, Cytomegalovirus, Herpes Simplex) manifested by high levels of corresponding antibodies. These cases were compared to other 100 subjects who were clinically healthy unrelated women with at least one previous uneventful pregnancy, taken as a control group. Their mean age \pm SD was $29 \pm 6.8$ years.

Peripheral blood was collected from the subjects in 2-mL EDTA tubes, and genomic DNA was isolated using a Puregene DNA isolation kit. To determine the polymorphisms 1154G/A, $2578 \mathrm{C} / \mathrm{A}, 634 \mathrm{C} / \mathrm{G}$, and $936 \mathrm{C} / \mathrm{T}$, genomic DNA was amplified using the primers (F5-TCCTGCTCCCTCCTCGCCAATG-3') (R5'GGCGGGGACAGGCGAGCATC-3`), (F5`-GGATGGGGCTGACTAGGTAAGC-3`) (R5`) AGCCCCCTTTTCCTCCAAC-3'), (F5'-ATTTATTTTTGTCTGTCTGTCTGTCCGTCA-3') (R5'TAGGCCAGACCCTGGCAC-3'), and (F5-AAGGAAGAGGAGACTCTGCGC-3`) (R5'TATGTGGGTGGGTGTGTCTACAG-3`). The PCR conditions were as follows: 5 min at $95^{\circ} \mathrm{C}$, followed by 35 cycles of denaturation at $94^{\circ} \mathrm{C}$ for $45 \mathrm{~s}$ annealing at $60^{\circ} \mathrm{C}$ for $45 \mathrm{~s}$, extension at $72^{\circ} \mathrm{C}$, and a final extension at $72^{\circ} \mathrm{C}$ for $7 \mathrm{~min}$ (Table 1). The PCR products were detected on a $2 \%$ agarose gel. Afterwards, the PCR products were digested with the restriction enzymes MnII, BgIII, BsfmI, and NIaII, and the digested products were detected on a $3 \%$ Ethidium bromide agarose gel.

Table 1: Primer sequences, restriction enzymes, PCR and enzyme digestion product sizes.

\begin{tabular}{|c|c|c|c|c|c|}
\hline Polymorphism & Primer F & Primer R & $\begin{array}{l}\text { PCR } \\
\text { product }\end{array}$ & $\begin{array}{l}\text { Restriction } \\
\text { enzyme }\end{array}$ & RFLP products \\
\hline $1154 \mathrm{G} / \mathrm{A}$ & $\begin{array}{l}5 ` \\
\text { TCCTGCTCCCTCCTCGCCAAT } \\
\text { G-3 }\end{array}$ & $\begin{array}{l}5 ` \\
\text { GGCGGGGACAGGCGAGCA } \\
\text { TC-3 }\end{array}$ & $206 b p$ & MnII & $\begin{array}{l}(\mathrm{G}) \\
150 \mathrm{bp} \\
34 \mathrm{bp} \\
22 \mathrm{bp} \\
(\mathrm{A}) \\
184 \mathrm{bp} \\
22 \mathrm{bp}\end{array}$ \\
\hline $2578 \mathrm{C} / \mathrm{A}$ & $\begin{array}{l}5 ` \\
\text { GGATGGGGCTGACTAGGTAA } \\
\text { GC-3 }\end{array}$ & $\begin{array}{l}5 ` \\
\text { AGCCCCCTTTTCCTCCAAC } \\
-3\end{array}$ & $324 b p$ & BgIII & $\begin{array}{l}\text { (A) } \\
202 \mathrm{bp} \\
122 \mathrm{bp} \\
(\mathrm{C}) \\
324 \mathrm{bp}\end{array}$ \\
\hline $634 \mathrm{C} / \mathrm{G}$ & $\begin{array}{l}\text { 5'- } \\
\text { ATTTATTTTTGTCTGTCTGTCT } \\
\text { GTCCGTCA-3' }\end{array}$ & $\begin{array}{l}5^{`}- \\
\text { TAGGCCAGACCCTGGCAC- } \\
33^{`}\end{array}$ & $304 b p$ & BsfmI & $\begin{array}{l}\text { (C) } \\
193 \mathrm{bp} \\
111 \mathrm{bp} \\
(\mathrm{G}) \\
304 \mathrm{bp}\end{array}$ \\
\hline $936 \mathrm{C} / \mathrm{T}$ & $\begin{array}{l}5 ` \\
\text { AAGGAAGAGGAGACTCTGCG } \\
\text { C-3 }\end{array}$ & $\begin{array}{l}` \\
\text { TATGTGGGTGGGTGTGTCT } \\
\text { ACAG-3` }\end{array}$ & $198 \mathrm{bp}$ & NIaII & $\begin{array}{l}\text { (C) } \\
198 \mathrm{bp} \\
\text { (A) } \\
112 \mathrm{bp} \\
86 \mathrm{bp}\end{array}$ \\
\hline
\end{tabular}

\section{Result}

The VEGF genotype and allele frequencies of the control and RA groups are shown in (Table 2) for the four VEGF polymorphisms. The genotype distribution of each polymorphism in the patients and controls was in Hardy-Weinberg equilibrium.

The genotype analysis and statistical results for VEGF -2578 C/A, -1154G/A, $-634 \mathrm{C} / \mathrm{G}$ and $-936 \mathrm{C} / \mathrm{T}$ are presented in table 2. In all statistical analyses, we performed four different comparisons: 


\section{VEGF -2578 C/A polymorphism and RA risk:}

$\mathrm{C} / \mathrm{C}, 55 \%$ were heterozygous $\mathrm{C} / \mathrm{A}$ and $15 \%$ were homozygous A/A. Among the 100 controls analyzed $66 \%$ were $\mathrm{C} / \mathrm{C}, 34 \%$ were $\mathrm{C} / \mathrm{A}$ and $0 \%$ were $\mathrm{A} / \mathrm{A}$. The $\mathrm{C}$ allele frequency was 0.57 in patients and 0.83 in controls and that of A was 0.42 and 0.17 in patients and controls respectively. The distribution of genotypes in patients and controls was in Hardy-Weinberg equilibrium (Table 2). The frequencies of the heterozygotes were significantly higher in both cases and controls suggesting that there could be selection operating in the population for this gene. With $\mathrm{C} / \mathrm{C}$ as the reference genotype, the $\mathrm{OR}(95 \% \mathrm{CI})$ for heterozygosity and homozygosity of A allele was determined. Significant difference was observed in the VEGF C/A genotypes between RA cases and controls, suggesting the association of VEGF C/A genotype and risk for RA (OR-2.37; 95\% CI 1.34 - 4.20) The logistic regression analysis after adjusting for age also revealed a significant association of VEGF and RA.

\section{VEGF -1154 G/A polymorphism and RA risk:}

The adjusted odds ratio (AOR) value of the GA genotype for the GG genotype of the $-1154 \mathrm{G}>\mathrm{A}$ polymorphism (Table 2) was significant trend between the patients with RA and the controls. The overall (GA+AA) frequency was also marginally significantly different between the controls and patients with RA.

\section{VEGF -634 C/G polymorphism and RA risk:}

The adjusted odds ratio (AOR) value of the CG genotype for the $\mathrm{CC}$ genotype of the $-634 \mathrm{C}>\mathrm{G}$ polymorphism (Table 2) was significant trend between the patients with RA and the controls.(AOR) value of the GG genotype for the CC genotype was highly significant trend between the patients with RA and Controls .

\section{VEGF -936 C/T polymorphism and RA risk:}

The genotype frequency of 936C $>\mathrm{T}$ polymorphism (Table 2 )was not significant trend between the patients with RA and the controls.

Table 2: Genotype frequencies of VEGF $-2578 \mathrm{C} / \mathrm{A},-1154 \mathrm{G} / \mathrm{A},-634 \mathrm{G} / \mathrm{C}$ and $-936 \mathrm{C} / \mathrm{T}$ polymorphisms in Egyptian women with recurrent abortion and in controls.

\begin{tabular}{|c|c|c|c|}
\hline & $\begin{array}{l}\text { Cases } \\
(n=100)\end{array}$ & $\begin{array}{l}\text { Control } \\
(\mathrm{n}=\mathbf{1 0 0})\end{array}$ & OR $(95 \%$ CI $)$ \\
\hline \multicolumn{4}{|l|}{ VEGF -2578C/A } \\
\hline $\mathrm{CC}$ & $30(30 \%)$ & $66(66 \%)$ & $0.22(0.12-0.40)$ \\
\hline $\mathrm{CA}$ & $55(55 \%)$ & $34(34 \%)$ & $2.37(1.34-4.20)$ \\
\hline AA & $15(15 \%)$ & $0(0 \%)$ & $2.18(1.86-2.55)$ \\
\hline $\mathrm{CA}+\mathrm{CC}$ & $70(70 \%)$ & $34(34 \%)$ & $4.53(2.50-8.21)$ \\
\hline Allele frequency (A) & $85(42.5 \%)$ & $34(17 \%)$ & $2.07(1.53-2.79)$ \\
\hline \multicolumn{4}{|l|}{ VEGF -1154G/A } \\
\hline GG & $56(56 \%)$ & $77(77 \%)$ & $0.38(0.21-0.70)$ \\
\hline GA & $38(38 \%)$ & $22(22 \%)$ & $2.17(1.17-4.05)$ \\
\hline $\mathrm{AA}$ & $6(6 \%)$ & $1(1 \%)$ & $6.32(0.75-53.48)$ \\
\hline $\mathrm{GA}+\mathrm{AA}$ & $44(44 \%)$ & $23(23 \%)$ & $2.63(1.43-4.84)$ \\
\hline Allele frequency $(\mathrm{A})$ & $60(30 \%)$ & $46(23 \%)$ & $1.021(0.95-1.54)$ \\
\hline \multicolumn{4}{|l|}{ VEGF -634G/C } \\
\hline $\mathrm{CC}$ & $19(19 \%)$ & $27(27 \%)$ & $0.63(0.33-1.24)$ \\
\hline CG & $64(64 \%)$ & $72(72 \%)$ & $0.69(0.38-1.26)$ \\
\hline GG & $17(17 \%)$ & $1(1 \%)$ & $20.28(2.64-155.6)$ \\
\hline $\mathrm{CG}+\mathrm{GG}$ & $81(81 \%)$ & $73(73 \%)$ & $1.58(0.81-3.07)$ \\
\hline Allele frequency $(\mathrm{G})$ & $98(49 \%)$ & $74(37 \%)$ & $1.28(0.96-1.72)$ \\
\hline \multicolumn{4}{|l|}{ VEGF $-936 \mathrm{C} / \mathrm{T}$} \\
\hline $\mathrm{CC}$ & $73(73 \%)$ & $78(78 \%)$ & $0.76(0.40-1.46)$ \\
\hline $\mathrm{CT}$ & $27(27 \%)$ & $22(22 \%)$ & $0.76(0.40-1.46)$ \\
\hline TT & $0(0 \%)$ & $0(0 \%)$ & -- \\
\hline $\mathrm{CT}+\mathrm{TT}$ & $27(27 \%)$ & $22(22 \%)$ & $1.31(0.69-2.51)$ \\
\hline Allele frequency $(\mathrm{T})$ & $27(13.5 \%)$ & $22(11 \%)$ & $1.13(0.82-1.57)$ \\
\hline
\end{tabular}

\section{Discussion}

Recurrent abortion (RA) has been associated with multiple causes, but in almost half of the cases, etiologies remain unknown. It is defined as the loss of three or more consecutive pregnancies prior to the 20th week of gestation and affects $5 \%$ of couples $(20,21)$. Several studies suggest that gene poly-morphisms encoding for different mediators may represent a susceptibility factor for unexplained RA.

VEGF has important roles in vascular permeability and angiogenesis, and regulates multiple endothelial cell functions. VEGF induces endothelial cell proliferation, migration and differentiation, and stimulates endothelial cell survival. Depending on its angiogenic and mitogenic properties, VEGF is important in embryonic development. The human placenta is rich in angiogenic factors such as VEGF, which plays an 
important role not only in forming placental vessels, but also in maternal vascular adaptation to pregnancy. In the placenta, vasculogenesis, the de novo synthesis of new blood vessels, accounts for the majority of new vessel formation during the first trimester, and is initially observed around day 21 post-coitum (22).

In this study, we studied VEGF $-2578 \mathrm{C} / \mathrm{A},-1154 \mathrm{G} / \mathrm{A},-634 \mathrm{C} / \mathrm{G}$ and $-936 \mathrm{C} / \mathrm{T}$ relation with recurrent abortion risk.

This study revealed a statistically significant difference higher frequency of homozygous mutant genotype (AA) of VEGF C2578A gen among cases compared to control, manifested by very high odds ratio $[\mathrm{OR}=2.18, \mathrm{P}=<0.001]$.

Also, there is a statistically significant difference lower frequency of normal wild genotype (CC) in VEGF C2578A gene among cases compared to controls [OR=0.22, $\mathrm{P}=<0.001]$.

Also this study revealed a statistically significant difference higher frequency of the over all of (GA) + (AA) of VEGF G1154A gen among cases compared to control, manifested by very high odds ratio [OR=2.63, $\mathrm{P}=<0.002]$.

Also, there is a statistically significant difference lower frequency of normal wild genotype (GG) in VEGF G1154A gene among cases compared to controls [OR=0.38, $\mathrm{P}=<0.002]$.

And also this study revealed a statistically significant difference higher frequency of homozygous mutant genotype (GG) of VEGF C634G gen among cases compared to control, manifested by very high odds ratio $[\mathrm{OR}=20.28, \mathrm{P}=<0.001]$.

Also, there is a statistically significant difference lower frequency of normal wild genotype (CC) in VEGF C634G gene among cases compared to controls [OR=0.63, $\mathrm{P}=<0.001]$.

On the other hand, there is no statistically significant difference in the frequency of homozygous mutant genotype (TT) in VEGF C936T gene among cases compared to controls [OR= NA, P=NA]. the same was observed on analysis the normal wild genotype (CC) in VEGF C936T gen among cases compared to controls $[\mathrm{OR}=0.76, \mathrm{P}=>0.05]$.

Ethnic heterogeneity is a key contributor to genetic association studies, including those on the association of VEGFA variant with RA, exemplified by the association of $-963 \mathrm{C} / \mathrm{T}$ with RSA in North Indians(23) and Greeks (24), but not in Brazilians (25) or Koreans (26).

In addition, the lack of association of RA with both $-634 \mathrm{G} / \mathrm{C}$ and $+963 \mathrm{C} / \mathrm{T}$ was reminiscent of Brazilian (27), Greek (24)and Korean (26) studies, but in disagreement with the studies on North Indians (23) where an association between RA and both VEGF variants was reported.

VEGF-1154G/A was not associated with RA among Bahraini women, in agreement with a recent study on Chinese Han women(28), and a large meta- analysis involving 2813 cases and 2830 controls (29). In contrast, studies on Koreans(26) and Caucasians (30) indicated association between-1154G/A and RA risk, and homozygosity of VEGF -1154 A/A gene was described to serve as a susceptibility factor affecting the outcome of recurrent implantation failure (31).

In addition, a small meta-analysis involving four eligible studies totaling 534 patients and 430 control women concluded that $-1154 \mathrm{G} / \mathrm{A}$ was significantly and consistently associated with RA, with OR (95\% CI) values of $1.51(1.13-2.03)(32)$.

These differences may be due to the result of differences in sample size, inclusion and exclusion criteria, as well as due to ethnic difference in -1154G/A genotype distribution, exemplified by the finding that polymorphism is less frequent among Chinese than Caucasians(24,30).

Samli et al studied VEGF-1154 G/A, -2578 C/A, and -936 C/T polymorphisms in 38 recurrent pregnancy loss (RPL) patients and 30 controls. They reported a relationship between -1154 G/A polymorphism and RPL and proposed that miscarriages would be due to VEGF's importance in placental angiogenesis (33).

Sinem Atik Yalcintepe et al studied VEGF A $-936 \mathrm{C} / \mathrm{T},-2578 \mathrm{C} / \mathrm{A}$ polymorphisms in relation with spontaneous abortion risk. VEGF A $-936 \mathrm{C} / \mathrm{T}$ genotype and the $\mathrm{T}$ allele are risk factors in fetal genome according to comparisons made with their mothers and healthy control group genotypes. VEGF A -2578 C/A polymorphism was not found to be a risk factor for spontaneous abortion (34).

\section{Conclusion}

Recurrent abortion among Egyptian women was strongly associated with the mutations related to VEGF gene polymorphism. Characteristically, these cases showed high frequencies of VEGF C2578A, G1154A, and C634G mutation. Interestingly, VEGF C2578A, G1154A, and C634G mutation frequencies were relatively higher among cases with recurrent abortion than VEGF C936T.

\section{For this reason we have to recommend,}

* Routine screening for recurrent abortion mutations for all Egyptian pregnant women in order to setup an appropriate method of prophylaxis against recurrent abortion disorder. 
* Population screening for VEGF C2578A, G1154A, and C634G carriers for detection of susceptible individuals to whom adequate programs can be implemented to prevent recurrent abortion.

\section{Reference}

[1]. Farquharson RG, Jauniaux E, Exalto N. Updated and revised nomenclature for description of early pregnancy events. Hum Reprod. 2005; 11: 3008-3011.

[2]. 2. Jauniaux E, Farquharson RG, Christiansen OB, Exalto N. Evidence-based guidelines for the investigation and medical treatment of recurrent miscarriage. Hum Reprod. 2006; 11: 2216-2222.

[3]. Silver RM, Branch DW, Goldenberg R, Iams JD, Klebanoff MA. Nomenclature for pregnancy outcomes: time for a change. Obstet Gynecol. 2011; 11: 1402-1408.

[4]. Younis JS,Ohel G,Brenner B, Ben-Ami M.Familial thrombophilia-the scientific rationale for thrombophylaxis in recurrent pregnancy loss? Hum Reprod 1997;12:1389-90.

[5]. Raziel A, Kornberg Y, Fridler S Schachter M, SelaBA, Ron-EL R. Hypercoagulable thromothilic defects and hyperhomocysteinemia in patient with recurrent pregnancy loss. Am J Reprod Immunol 2001;45:65-71.

[6]. Yamada H, Kato EH, Kobashi G, Ebina Y, Shimada S, Morikawa M, et al. Recurrent pregmancy loss: etiology of thrombophilia. Semin Thromb Hemost 2001;27:121-9.

[7]. Li TC, Makris M, Tomsu, Tuckerman E, Laird S. Recurrent miscarriage: etiology, management and prognosis. Hum Reprod Update 2002;8:463-81.

[8]. Eller AG, Branch DW, Nelson L, et al. Vascular endothelial growth factor-A gene polymorphisms in women with recurrent pregnancy loss. J Reprod Immunol 2011;88:48-52.

[9]. Zygmunt M, Herr F, Munstedt K, et al. Angiogenesis and vasculogenesis in pregnancy. Eur J Obstet Gynecol Reprod Biol2003;110 Suppl 1:S10-8.

[10]. Vuorela P, Carpen O, Tulppala M, et al. VEGF, its receptors and the tie receptors in recurrent miscarriage. Mol Hum Reprod2000;6:276-82.

[11]. Awata T, Inoue K, Kurihara S, et al. A common polymorphism in the 5'-untranslated region of the VEGF gene is associated with diabetic retinopathy in type 2 diabetes. Diabetes2002;51:1635-9.

[12]. Mohammadi M, Day PJ. The influence of immunosuppressive drugs on vascular endothelial growth factor production in relation to VEGF -1154 g and -2578 C genotypes. Iran J Immunol 2010;7:217-25.

[13]. Abe A, Sato K, Habuchi T, et al. Single nucleotide polymorphisms in the 3' untranslated region of vascular endothelial growth factor gene in Japanese population with or without renal cell carcinoma. Tohoku J Exp Med2002;198:181-90.

[14]. Shahbazi M, Fryer AA, Pravica V, et al. Vascular endothelial growth factor gene polymorphisms are associated with acute renal allograft rejection. J Am Soc Nephrol 2002;13:260-4.

[15]. 11. Howell WM, Bateman AC, Turner SJ, et al. Influence of vascular endothelial growth factor single nucleotide polymorphisms on tumour development in cutaneous malignant melanoma. Genes Immun 2002;3:229-32.

[16]. Kataoka N, Cai Q, Wen W, et al. Population-based casecontrol study of VEGF gene polymorphisms and breast cancer risk among Chinese women. Cancer Epidemiol Biomarkers Prev2006;15:1148-52.

[17]. Bradbury PA, Zhai R, Ma C, et al. Vascular endothelial growth factor polymorphisms and esophageal cancer prognosis. Clin Cancer Res 2009; 15:4680-5.

[18]. Howell WM, Ali S, Rose-Zerilli MJ, et al. VEGF polymorphisms and severity of atherosclerosis. J Med Genet2005;42:485-90.

[19]. Su MT, Lin SH, Chen YC. Genetic association studies of angiogenesis- and vasoconstriction-related genes in women with recurrent pregnancy loss: a systematic review and meta-analysis. Hum Reprod Update 2011;17:803-12.

[20]. Stirrat GM. Recurrent miscarriage. II: clinical associations, causes and management. Lancet 1990; 336: 728-733.

[21]. Branch DW, Gibson M, Silver RM. Clinical practice. Recurrent miscarriage. N Engl J Med. 2010; 11: 1740-1747.

[22]. Demir R, Kaufmann P, Castellucci M, et al. Fetal vasculogenesis and angiogenesis in human placental villi. Acta Anat (Basel) 1989;136:190-203.

[23]. Aggarwal S, Parveen F, Faridi RM, Phadke S, Borkar M, Agrawal S. Vascular endothelial growth factor gene polymorphisms in North Indian patients endothelial growth factor gene polymorphisms in North Indian patients with recurrent miscarriages. Reprod Biomed Online 2011; 22(1): 59-64.

[24]. Papazoglou D, Galazios G, Papatheodorou K, Liberis V, Papanas N, Maltezos E. Vascular endothelial growth factor gene polymorphisms and idiopathic recurrent pregnancy loss. Fertil Steril. 2005; 83(4): 959-63.

[25]. Traina E, Daher S, Moron AF, Sun SY, Franchim CS, Mattar R. Polymorphisms in VEGF, progesterone receptor and IL-1 receptor genes in women with recurrent spontaneous abortion. J Reprod Immunol 2011; 88(1): 53-7.

[26]. Lee HH, Hong SH, Shin SJ, Ko JJ, Oh D, Kim NK. Association study of vascular endothelial growth factor polymorphisms with the risk of recurrent spontaneous abortion. Fertil Steril. 2010; 93(4): 1244-7.

[27]. Traina E, Daher S, Moron AF, Sun SY, Franchim CS, Mattar R. Polymorphisms in VEGF, progesterone receptor and IL-1 receptor genes in women with recurrent spontaneous abortion. J Reprod Immunol 2011; 88(1): 53-7.

[28]. Xing X, Yan J, Zhao Y, You L, Bian Y, Chen ZJ (2011). Association of vascular endothelial growth factor gene polymorphisms with recurrent spontaneous abortion in Chinese Han women. Am J Reprod Immunol. 2011; 65(5):521-5.

[29]. Zhang B, Dai B, Zhang X, Wang Z (2012). Vascular endothelial growth factor and recurrent spontaneous abortion: a meta-analysis. Gene. 2012; 507(1):1-8.

[30]. Coulam CB, Jeyendran RS. Vascular endothelial growth factor gene polymorphisms and recurrent pregnancy loss. Am J Reprod Immunol 2008; 59: 301-305.

[31]. Goodman C, Jeyendran RS, Coulam CB (2008). Vascular endothelial growth factor gene polymorphism and implantation failure. Reprod Biomed Online 2008; 16(5): 720-3.

[32]. Su MT, Lin SH, Chen YC. Genetic association studies of angiogenesis- and vasoconstriction-related genes in women with recurrent pregnancy loss a systematic review and meta-analysis. Hum Reprod Update 2011; 17: 803-812.

[33]. Samli H, Demir BC, Ozgoz A, et al. Vascular endothelial growth factor gene 1154 G/A, 2578 C/A, 460 C/T, 936C/T polymorphisms and association with recurrent pregnancy losses. Genet Mol Res 2012; 11: 4739-45.

[34]. Sinem AY, Fatma S, Servet O H, Ahmet U, Emine C. Fetal VEGF Genotype is More Important for Abortion Risk than Mother Genotype. Int J Mol Cell Med Spring 2014; Vol 3 No 2. 